JPPIPA, Vol. 3 No. 22018
Jurnal Penelitian Pendidikan IPA
http://journal.unesa.ac.id/index.php/jppipa

\title{
PENGEMBANGAN LEMBAR KERJA MAHASISWA (LKM) MATA KULIAH DASAR-DASAR IPA BERBASIS MODEL ALLR (ACTIVITY BASED-LESSON LEARN-REFLECTION) UNTUK MENINGKATKAN KETERAMPILAN PROSES SAINS DAN PENDIDIKAN KARAKTER CALON GURU IPA
}

Oleh:

Dhita Ayu Permata Sari ${ }^{1}$, Wahono Widodo ${ }^{1}$, Martini ${ }^{1}$, Totok Suyanto ${ }^{2}$

${ }^{1}$ Jurusan Sains, Fakultas Matematika dan IPA, Universitas Negeri Surabaya, Negara Indonesia

${ }^{2}$ Jurusan Kewarganegaraan, Fakultas Ilmu Sosial dan Hukum, Universitas Negeri Surabaya, Negara Indonesia

\begin{abstract}
Abstrak
Penelitian ini bertujuan untuk mengembangkan Lembar Kerja Mahasiswa (LKM) Dasar-dasar IPA yang diharapkan dapat membekali mahasiswa calon guru IPA dengan keterampilan proses sains sekaligus nilai-nilai positif melalui pendidikan karakter. Pendidikan karakter ini dianggap perlu karena maraknya konflik-konflik intoleransi dan keadilan sosial yang terjadi di masyarakat akhi-akhir ini. Hal ini menunjukkan bahwa nilai-nilai integritas bangsa Indonesia perlu mendapatkan perhatian, terutama dalam hal etika, moral, dan kepercayaan. Pentingnya nilai-nilai ini karena semangat gotong royong dan saling bekerjasama merupakan karakter Bangsa Indonesia. LKM yang dikembangkan melalui tahapan perancangan, penyusunan, validasi, dan revisi sehingga dihasilkan produk LKM Dasar-dasar IPA berbasis model ALLR (Activity Based-Lesson Learn-Reflection). Hasil pengembangan LKM menghasilkan empat kegiatan LKM yang dibagi menurut topik pembahasan yang berbeda-beda dengan menggunakan serangkaian aktivitas yang diharapkan dapat meningkatkan keterampilan proses sains. Selain itu, LKM juga dirancang untuk pengintegrasikan pendidikan melalui pembelajaran pemaknaan konten-konten IPA ke dalam nilai-nilai positif yang berkaitan dengan nilai toleransi dan keadilan sosial. Hasil validasi menunjukkan bahwa LKM Dasar-dasar IPA layak digunakan dengan nilai presentase validasi LKM 1 sebesar 76.79\%, LKM 2 sebesar 82.14\%, LKM 3 sebesar 92.85\%, dan LKM 4 sebesar $76.78 \%$.
\end{abstract}

Kata Kunci: LKM Dasar-dasar IPA, Keterampilan Proses Sains. Toleransi, Keadilan sosial

\begin{abstract}
The aim of this research is to develop Student Workbook of Basic Natural Science Course in order to prepare preservice teachers with scientific process skills and good characters, especially tolerance and social justice attitudes. Character education is important because lately some social conflicts appeared in society. Thus, the integrity values of Indonesian people need to be emphasize, especially in ethics, moral, and religion, because cooperation is the characteristics of Indonesian people. The stages of Student Workbook development are design, preparation, validation, and revision, so that Students Workbook based on ALLR (Activity Based-Lesson Learn-Reflection) learning model is created. The result of development process is four activities in Student Workbook with different topic to be discussed by students in order to enhance pre-service teachers' scientific process skills. In addition, The Student Workbook also integrate character education activities by adding "Character Building" boxes that will remind students with character education related to tolerance and social justice values. The results of the validation show that the worksheet can be applied and feasible in class with percentage of validation for 1st activities is $76.79 \%$, 2nd activities is $82.14 \%$, 3rd activities is $92.85 \%$, and 4 th activities is $76.78 \%$.
\end{abstract}

Keywords: Natural Science Student Workbook, Science Process Skills, Tolerance and Social Justice Value

(C) 2018 Universitas Negeri Surabaya

${ }^{2}$ Alamat Korespondensi:

Jurusan IPA, Fakultas Matematika dan IPA, Universitas Negeri

p-ISSN: $2527-7537$

Surabaya

e-ISSN: 2549-2209

Gedung C12, FMIPA, Unesa

E-mail: dhitasari@unesa.ac.id

\section{PENDAHULUAN}

Pendidikan karakter ini sangat penting bagi calon guru IPA sebagai bekal mengajar dan bersosialisasi di masyarakat Indonesia yang majemuk dalam hal suku, agama, dan ras (SARA) yang menyebar dari Sabang sampai Merauke. Jika 58 
Pemuda pada tanggal 28 Oktober 1928 telah menyatukan Bangsa Indonesia untuk mewujudkan keadilan dan kemakmuran bagi rakyat Indonesia. Namun, kendala-kendala yang dihadapi hingga saat ini terus bermunculan.

Hasil survei nasional bertajuk "Potensi Intoleransi dan Radikalisme Sosial Keagamaan di Kalangan Muslim Indonesia" yang digelar Wahid Foundation bekerja sama dengan Lembaga Survei Indonesia (LSI) menunjukkan bahwa dari 1.520 responden yang tersebar di 34 provinsi sebanyak 59,9 persen memiliki kelompok yang dibenci. Sebesar 92,2 persen menyatakan tidak setuju bila anggota kelompok yang dibenci tersebut menjadi pejabat pemerintah Indonesia. Lebih ekstrim lagi sebanyak 82,4 persen tidak rela kelompok tersebut menjadi tetangga mereka.Hanya 7,7 persen bersedia melakukan tindakan radikal dan 0,4 persen pernah melakukan tindakan radikal (Hakim, 2016a).

Maraknya konflik-konflik intoleransi dan keadilan sosial menunjukkan mulai terkikisnya nilai-nilai integritas bangsa Indonesia terutama dalam hal etika, moral, dan kepercayaan. Karakter bangsa yang memiliki semangat gotong royong dan saling bekerja sama demi kemajuan bangsa mulai memudar. Padahal inilah yang menjadi karakter Bangsa Indonesia. Jika ini dibiarkan terus berlanjut dan konflik-konflik serupa terus timbul, maka akan menimbulkan efek jangka panjang yang mempengaruhi berbagai bidang di Indoneisa, terutama perekonomian yang saat ini memang masih tertinggal jauh dari negara-negara lain.

Dalam menghadapi hal tersebut, diperlukan suatu rekayasa sosial di berbagai komponen kehidupan berbangsa, bernegara, dan bermasyarakat di Indonesia. Salah satunya dapat dilakukan di bidang pendidikan melalui pendidikan karakter yang dapat menguatkan sikap toleransi dan keadilan sosial mahasiswa melalui pembelajaran di tingkat pendidikan tinggi. Pendidikan karakter ini tidak hanya dilakukan pada mata kuliah Pendidikan Kewarganegaraan atau Pendidikan Pancasila saja, namun dapat diintegrasikan dalam mata kuliah bidang studi IPA. Salah satunya di bidang pendidikan dengan melaksanakan pendidikan karakter dalam pembelajaran, terutama dalam sikap toleransi dan keadilan sosial.

Undang-undang RI No. 2 Tahun 1989 menyatakan bahwa mendidik merupakan suatu usaha untuk menyiapkan peserta didik melalui kegiatan bimbingan, pengajaran, dan/atau latihan bagi peranannya di masa yang akan datang. Dengan demikian,guru merupakan pembimbing, pengajar, dan pelatih. Guru tidak hanya bertugas untuk mengajarkan suatu bidang ilmu tertentu saja, namun juga berperan dalam memahami makna yang lebih luas. Guru harus dapat menanamkan konsep berpikir melalui proses pembelajaran yang diberikan. Selain itu, guru juga bertindak sebagai pembimbing yang dapat membuat peserta didik menolong dirinya sendiri sehingga peserta didik berlatih memiliki jiwa yang mandiri. Selain itu, guru merupakan cerminan bagi peserta didik. Di sinilah peran guru sebagai contoh bagi siswanya.

Pendidikan Karakter merupakan salah tujuan Unesa, termasuk Jurusan IPA di dalamnya, untuk mencetak calon guru IPA di sekolah. Pembelajaran IPA di sekolah memiliki tujuan meningkatkan keterampilan bekerja dan berpikir secara sistematis menurut prosedur ilmiah (Trianto, 2010). Keterampilan bekerja dan berpikir ini berkaitan dengan keterampilan proses sains. Peningkatan keterampilan proses sains dapat dilakukan dengan melakukan serangkaian aktivitas untuk mempelajari fenomena alam yang terjadi di sekitar, salah satunya dengan kegiatan eksplorasi melalui kegiatan penyelidikan di laboratorium. Kegiatan penyelidikan dan pemecahan masalah dengan menggunakan langkah metode ilmiah melalui kegiatan praktikum membuat pebelajar terlibat langsung dalam kegiatan belajar sehingga dapat mempermudah pebelajar untuk menerima materi pelajaran (Prasasti, 2017).

Seiring dengan kegiatan tersebut, pembelajaran IPA juga menekankan pada penguatan sikap-sikap ilmiah dalam memecahkan permasalahan yang terjadi misalnya sikap skeptis, kritis, sensitif, objektif, jujur, terbuka, dan dapat bekerja sama (Carin, 1990). Dengan demikian, pembelajaran IPA tidak hanya mempelajari konten-konten yang berkaitan dengan fenomena alam saja namun juga memuat pendidikan karakter di dalamnya yang dapat menumbuhkan sikap-sikap positif (Shumow, 2015).

Pendidikan karakter yang diintegrasikan dalam pembelajaran berbagai bidang studi dapat memberikan pengalaman yang bermakna bagi pebelajar karena mereka memahami, menginternalisasi, dan mengaktualisasikan melalui poses pembelajaran. Pendidikan karakter dengan pendekatan komprehensif, yang dipadukan dengan pembelajaran bidang studi dan dilandasi pengembangan budaya sekolah, dapat meningkatkan hasil studi dan kualitas karakter peserta didik (Zuchdi, 2010). Pada akhirnya, nilainilai tersebut dapat terserap secara alami lewat kegiatan sehari-hari.

Sementara itu, pelaksanaan pembelajaran yang baik tentunya membutuhkan suatu tindakan yang tepat sehingga tujuan pembelajaran dapat tercapai. Tindakan ini memerlukan suatu persiapan 
pembelajaran, pelaksaan pembelajaran, hingga evaluasi pembelajaran yang baik.

Berdasarkan hasil penelitian yang telah dilakukan di Jurusan IPA FMIPA Unesa menunjukkan bahwa pendidikan karakter telah dilakukan terkait dengan nilai-nilai moral di kelas melalui tiga cara, yaitu (1) kerja kelompok, (2) pembelajaran pemaknaan, dan (3) pembelajaran yang mengangkat tema etnosains dengan menghargai budaya lokal. Penyisipan nilai moral dalam perkuliahan cenderung dilakukan oleh dosen-dosen senior karena dosen-dosen senior memiliki pengalaman dan pengetahuan yang lebih mendalam sehingga bisa lebih mudah mengaitkan konsep dengan nilai-nilai positif (Widodo, 2016a). Dengan demikian dilakukan penelitian untuk mempersiapkan pelaksanaan pembelajaran dalam bidang studi IPA yang mengajarkan kontenkonten materi IPA dan pendidikan karakter, terutama sikap toleransi dan keadilan sosial.

Salah satu mata kuliah yang dipelajari oleh mahasiswa calon guru IPA di Jurusan IPA FMIPA Unesa adalah Dasar-dasar IPA. Mata kuliah Dasar-dasar IPA ini membahas tentang konsepkonsep dasar IPA yang dipelajari melalui kegiatan eksplorasi, elaborasi, dan konfirmasi terhadap fenomena-fenomena alam. Pembelajaran Dasardasar IPA dirancang dengan kegiatan pembelajaran yang melibatkan peran aktif mahasiswa di kelas dan praktikum di labororium. Pada mata kuliah dasar-dasar IPA belum menggunakan Lembar Kerja Mahasiswa yang digunakan untuk mempelajari konsep-konsep dasar IPA yang sekaligus mengintegrasikan pendidikan karakter di dalamnya. Dengan alasan itulah, dilakukan kegiatan yang mengembangkan LKM Dasar-dasar IPA dengan berbasis pada model ALLR (Activity Based-Lesson LearnReflection).

Artikel ini mendeskripsikan hasil penelitian yang mempersiapkan Lembar Kerja Mahasiswa Mata Kuliah Dasar-dasar IPA untuk mendukung pelaksanaan pembelajaran dengan menggunakan Model Pembelajaran ALLR. Model Pembelajaran ALLR merupakan model pembelajaran yang menekankan pada pembelajaran IPA melalui pengamatan fenomena alam serta menekankan pada penguatan sikap toleransi dan keadilan sosial melalui pengambilan hikmah untuk memaknai pesan-pesan moral yang tersirat dalam kontenkonten materi IPA (Widodo, 2018b). Sintaks model ALLR, yaitu (1) orientasi mahasiswa pada fenomena atau masalah yang akan diselidiki, (2) perancangan proses penyelidikan atau penyelesaian masalah, (3) pembimbingan penyelidikan atau penerapan metode penyelesaian masalah, (4) presentasi hasil penyelidikan atau penyelesaian masalah, (5) pengambilan hikmah/ pemaknaan konten IPA, dan (6) refleksi (Widodo, 2018b).

LKM Dasar-dasar IPA yang dikembangkan tidak mengajarkan keterampilan proses sains dengan kegiatan yang berpusat pada mahasiswa untuk menyelesaikan permasalahan yang terkait dengan sturktur, fungsi, dan proses fisiologis tumbuhan, namun juga menguatkan sikap toleransi dan keadilan sosial. Penguatan sikap toleransi dan keadilan sosial ini dilakukan melalui pemaknaan konten-konten IPA yang telah dipelajari dalam kegiatan pengambilan hikmah di akhir pembelajaran. Setelah itu, mahasiswa diarahkan untuk melakukan refleksi kegiatan yang telah dipelajari terhadap diri sendiri dan teman sebayanya. Kegiatan-kegiatan yang dirancang dalam penelitian ini diharapkan dapat meningkatkan keterampilan proses sains mahasiswa sekaligus menguatkan sikap toleransi dan keadilan sosial selama proses pembelajaran berlangsung.

\section{METODE}

Penelitian ini merupakan penelitian pengembangan (Research and Development) yang merupakan kegiatan merancang (desain) yang tidak rutin, sehingga ada kontribusi baru baik dalam bentuk proses maupun produk (Sugiyono, 2008). Tahapan atau prosedur penelitian ini terbagi menjadi tiga tahap, yaitu: (a) tahap 1 pembuatan rancangan pembelajaran dalam pengembangan LKM; (b) tahap 2 penyusuan draf LKM; dan (c) tahap 3 tinjauan ahli materi (Validasi) dan revisi. Data hasil penelitian dianalisis secara deskriptif selama proses uji formatif dalam hal ini proses pengembangan LKM Dasar-dasar IPA.

\section{HASIL DAN PEMBAHASAN}

Proses pengembangan LKM Dasar-Dasar IPA berbasis model pembelajaran ALLR dilakukan mulai dari analisis tujuan dan karakteristik isi mata kuliah Dasar-dasar IPA, analisis sumber belajar, analisis karakteristik mahasiswa, menentukan indikator dan strategi pembelajaran, pengukuran hasil pembelajaran, penyusunan draf LKM, validasi LKM, dan revisi LKM.

\section{Analisis Tujuan dan Karakteristik Isi Mata Kuliah Dasar-dasar IPA}

Analisis tujuan mata kuliah dilakukan untuk merancang capaian pembelajaran mata kuliah (kompetensi). Analisis karakteristik isi mata kuliah dilakukan untuk mengetahui isi mata kuliah yang dipelajari oleh mahasiswa. Deskripsi Mata Kuliah Dasar-dasar IPA, yaitu "Mata kuliah ini membahas tentang hakikat dan ruang lingkup IPA, 
IPA sebagai inkuiri, keterampilan proses sains (KPS), aspek konten IPA, fungsi IPA dalam penumbuhan kecakapan berpikir dan literasi sains." Sementara capaian pembelajaran mata kuliah (kompetensi) Mata Kuliah Dasar-dasar IPA adalah (1) memanfaatkan IPTEKS sebagai alat bantu pengembangan IPA, (2) menguasai hakikat dan ruang lingkup IPA, IPA sebagai inkuiri, KPS, analisis aspek konten IPA, kecakapan berpikir dan literasi, (3) terampil melakukan kegiatan inkuiri ilmiah dengan konten dan konteks kurikulum SMP/MTs, dan (4) mengembangkan sikap ilmiah mahasiswa yang bertanggung jawab terbuka atas kritik, kerja sama, dan peduli waktu.

\section{Analisis Sumber Belajar}

Sumber belajar yang digunakan dalam Mata Kuliah Dasar-dasar IPA berupa buku teks tentang pembelajaran IPA, buku BSE IPA SMP, dan artikel-artikel terkait pengembangan pembelajaran IPA. Buku teks yang digunakan adalah Science for All American, Pengembangan Pembelajaran IPA, dan Sains Dasar. Sementara buku BSE IPA yang digunakan adalah buku BSE IPA SMP yang sesuai dengan kurikulum 2013. Artikel-artikel terkait pembelajaran IPA dapat dikunjungi oleh mahasiswa melalui jurnal-jurnal online yang dilanggan oleh Unesa.

\section{Analisis Karakteristik Mahasiswa}

Mahasiswa yang memprogram Mata Kuliah Dasar-dasar IPA adalah mahasiswa semester III yang memiliki latar belakang, minat, dan kemampuan yang beragam. Hal ini terlihat dari hasil belajar mahasiswa yang dicapai pada semester-semester sebelumnya yang mencapai Indeks Prestasi Kumulatif (IPK) bervariasi.

\section{Menentukan Indikator dan Strategi Pembelajaran}

Indikator-indikator pembelajaran dirumuskan dalam tujuan pembelajaran yang dituliskan dalam setiap kegiatan LKM Mata Kuliah Dasar-dasar IPA. Tujuan Pembelajaran tersebut adalah adalah (1) mahasiswa dapat menemukan faktor-faktor yang mempengaruhi kapilaritas, (2) mahasiswa dapat menemukan model dari peran vegetasi dalam mengurangi global warming, (3) mahasiswa dapat menemukan model matematis pengaruh gaya terhadap pertambahan panjang pegas, (4) mahasiswa dapat menemukan model matematis dari proses pembentukan ikatan ion, dan (5) mahasiswa mampu bekerja sama, menerapkan sikap kekeluargaan, dan bergotong royong dalam melakukan percobaan. Tujuan pembelajaran 1 sampai dengan 4 merupakan tujuan pembelajaran yang berkaitan dengan penguasaan konten IPA, sedangkan tujuan pembelajaran 5 merupakan tujuan pembelajaran yang berkaitan dengan penguatan sikap toleransi dan keadilan sosial yang diwujudkan dalam kegiatan mahasiswa. Dengan demikian, strategi yang dipilih dalam pembelajaran adalah strategi yang dapat membuat mahasiswa mengembangkan sikap bekerja sama, kekeluargaan, dan gotong royong dalam percobaan melalui kegiatan diskusi kelompok.

\section{Pengukuran Hasil Pembelajaran}

Pengkukuran hasil pembelajaran mahasiswa dilakukan dengan menggunakan instrumen penilaian laporan kinerja mahasiswa berupa laporan praktikum yang disertai dengan rubrik penilaian laporan praktikum. Penilaian ini merupakan penilaian otentik yang dapat menilai keterampilan proses sains mahasiswa.

\section{Penyusunan Draf Pengembangan LKM} Dasar-dasar IPA

Draf pengembangan LKM Dasar-dasar IPA tersusun atas (1) kata pengantar, (2) Daftar Isi, (3) Isi LKM yang terdiri dari empat kegiatan sebagai berikut.

1. LKM 1 Inkuiri dalam IPA (Faktor-faktor yang Mempengaruhi Kapilaritas)

2. LKM 2 Pemodelan dalam IPA (Kasus Peran Vegetasi dalam Mengurangi Global Warming)

3. LKM 3 Pemodelan Matematis dalam IPA (Kasus Pengaruh Gaya terhadap Pertambahan Panjang Pegas)

4. LKM 4 Pemodelan Matematis dalam IPA (Kasus Pembentukan Ikatan Ion)

LKM yang dikembangkan memiliki berisi tentang judul kegiatan, tujuan pembelajaran, aktivitas yang diharapkan dapat meningkatkan keterampilan proses sains mahasiswa, aktivitas pengambilan hikmah untuk memaknai kontenkonten IPA berkaitan dengan sikap-sikap toleransi dan keadilan sosial, dan aktivitas refleksi diri dan teman sebaya.

Judul setiap LKM dibuat sesuai dengan tujuan pembelajaran yang akan dicapai. Selain itu, di awal kegiatan terdapat fitur Pertanyaan Prasyarat yang bertujuan untuk menggali pengetahuan awal mahasiswa terkait konten IPA yang akan dipelajari. Gambar 1 menunjukkan contoh tampilan judul dan tujuan LKM 1.

Di awal kegiatan dimasukkan bahan kajian yang mengarahkan mahasiswa pada topik yang dibahas dalam kegiatan tersebut. Selain itu, fitur Character Building mengingatkan mahasiswa untuk bekerja sama dengan sikap kekeluargaan dan gotong royong dalam menyelesaikan permasalahan dalam LKM 1. Fitur ini diharapkan dapat menjadi pengingat dan penguatan sikap 
toleransi dan keadilan sosial selama proses pembelajaran. Gambar 2 menunjukkan contoh tampilan bahan kajian awal dan fitur "Character Building" dalam LKM 1.

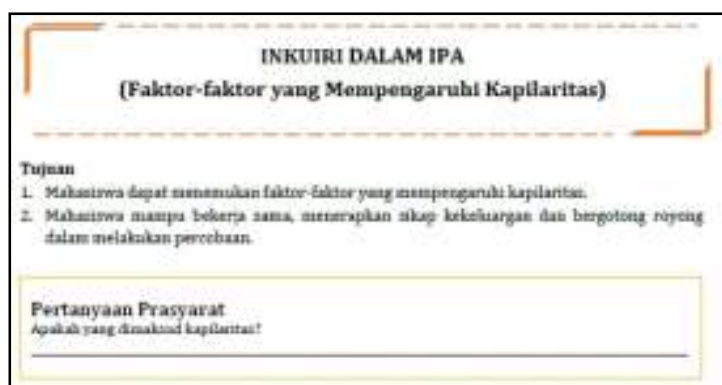

Gambar 1 Tampilan Judul, Tujuan, dan Pertanyaan Prasyarat LKM 1 MK

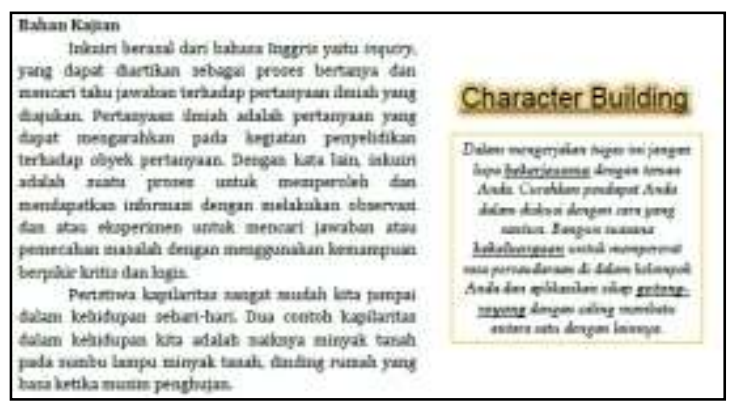

Gambar 2 Tampilan Bahan Kajian Awal dan Fitur "Character Building” LKM 1

Selanjutnya, kegiatan yang terdapat dalam LKM Mata Kuliah Dasar-dasar IPA diharapkan dapat meningkatkan keterampilan proses sains mahasiswa yang dimulai dari mengobservasi fenomena alam, merumuskan masalah, merumuskan hipotesis, merencanakan penyelidikan, melakukan eksperimen/penelitian, menganilis data, dan menarik kesimpulan. Dalam LKM Mata Kuliah Dasar-dasar IPA juga telah dicantumkan rumusan masalah, hipotesis, alat, bahan, dan prosedur kerja. Namun, mahasiswa diberi kesempatan untuk mengkaji ulang alat, bahan, dan prosedur kerja yang tercantum dalam LKM. Mahasiswa bersama dengan kelompoknya dapat merancang ulang kegiatan yang akan dilakukan.
Kegiatan dalam LKM Mata Kuliah Dasardasar IPA akan diakhiri dengan aktivitas pengambilan hikmah dan refleksi. Pengambilan hikmah merupakan kegiatan pemaknaan tentang konsep-konsep IPA berkaitan dengan sikap toleransi dan keadilan sosial. Dalam LKM diberikan contoh konsep-konsep IPA dapat menganalogikan sikap toleransi dan keadilan yang terlihat dalam fenomena-fenomena alam di sekitar. Setelah itu, mahasiswa diminta memberikan contoh lainnya sesuai dengan konten pembelajaran yang telah dilakukan. Kegiatan berikutnya adalah refleksi diri terkait konten IPA yang telah dipelajari, wujud sikap toleransi, dan keadilan sosial yang dilakukan selama proses belajar dengan menggunakan instrument refleksi diri dan teman sebaya. Gambar 3 menunjukkan tampilan aktivitas Pengambilan Hikmah dan Refleksi dalam LKM 1.

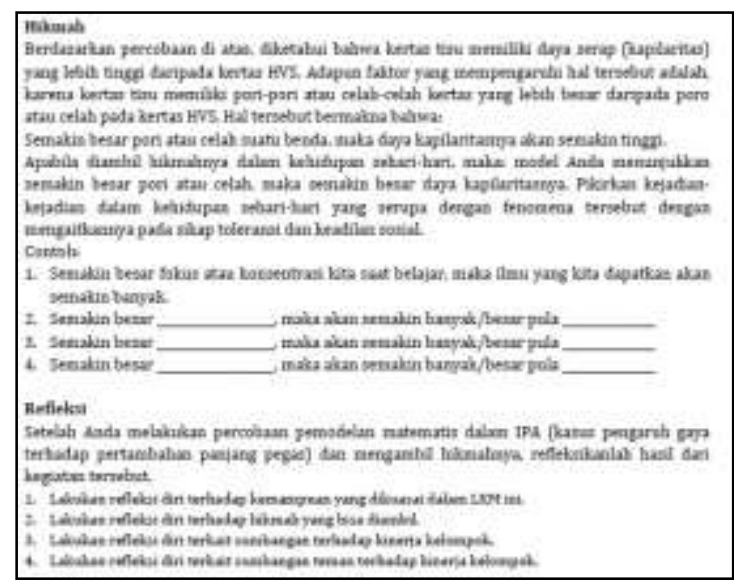

Gambar 3 Tampilan Hikmah dan Refleksi pada LKM 1

\section{Validasi LKM Dasar-dasar IPA}

LKM Dasar-dasar IPA yang telah disusun selanjutnya divalidasi oleh pakar yaitu tiga dosen Jurusan IPA. Validasi dilakukan melalui dua tahap. Tahap pertama, validator memberikan hasil validasinya sesuai dengan Tabel 1 . Masukan dari validator digunakan sebagai bahan revisi. Setelah itu, LKM yang telah divalidasi, divalidasi kembali di tahap 2 dengan hasil validasti seperti yang tertera dalam Tabel 1.

Tabel 1 Hasil Validasi LKM Dasar-dasar IPA Tahap 1 dan Tahap 2

\begin{tabular}{|l|l|l|l|l|l|l|l|l|l|}
\hline \multirow{2}{*}{ No. } & \multirow{2}{*}{ Komponen } & \multicolumn{3}{|c|}{ Modus Hasil Validasi LKM } \\
\cline { 3 - 9 } & & \multicolumn{5}{|c|}{ Tahap 1 } & \multicolumn{3}{c|}{ Tahap 2 } \\
\cline { 3 - 9 } & & $\mathbf{1}$ & $\mathbf{2}$ & $\mathbf{3}$ & $\mathbf{4}$ & $\mathbf{1}$ & $\mathbf{2}$ & $\mathbf{3}$ & $\mathbf{4}$ \\
\hline 1. & LKM sesuai dengan model ALLR. & 4 & 4 & 4 & 4 & 4 & 4 & 4 & 4 \\
\hline 2. & Informasi dalam panduan LKM dapat dipahami. & 3 & 3 & 3 & 3 & 3 & 3 & 4 & 3 \\
\hline 3. & LKM berisi masalah yang perlu dipecahkan. & 3 & 3 & 3 & 3 & 3 & 3 & 4 & 3 \\
\hline 4. & $\begin{array}{l}\text { Masalah dalam LKM dapat membantu meningkatkan } \\
\text { keterampilan memecahkan masalah mahasiswa. }\end{array}$ & 3 & 3 & 3 & 3 & 3 & 3 & 4 & 3 \\
\hline
\end{tabular}




\begin{tabular}{|c|c|c|c|c|c|c|c|c|c|}
\hline \multirow{3}{*}{ No. } & \multirow{3}{*}{ Komponen } & \multicolumn{8}{|c|}{ Modus Hasil Validasi LKM } \\
\hline & & \multicolumn{4}{|c|}{ Tahap 1} & \multicolumn{4}{|c|}{ Tahap 2} \\
\hline & & 1 & 2 & 3 & 4 & 1 & 2 & 3 & 4 \\
\hline 5. & $\begin{array}{l}\text { Masalah tersebut merupakan penerapan konsep-konsep } \\
\text { dalam bidang studi IPA. }\end{array}$ & 3 & 3 & 2 & 3 & 3 & 3 & 3 & 3 \\
\hline 6. & $\begin{array}{l}\text { Masalah dalam LKM dapat dipecahkan dengan scaffolding } \\
\text { dosen. }\end{array}$ & 3 & 3 & 2 & 3 & 3 & 4 & 4 & 3 \\
\hline 7. & $\begin{array}{l}\text { Arahan dalam LKM dapat berfungsi sebagai "bantuan" } \\
\text { bagi mahasiswa. }\end{array}$ & 2 & 2 & 2 & 3 & 3 & 3 & 3 & 3 \\
\hline 8. & Informasi dalam panduan LKM dapat dipahami. & 3 & 3 & 2 & 3 & 3 & 3 & 3 & 3 \\
\hline 9. & Alternatif jawaban dalam panduan LKM jelas. & 1 & 1 & 3 & 3 & 3 & 3 & 3 & 3 \\
\hline 10. & $\begin{array}{l}\text { Alternatif jawaban dalam panduan LKM dapat digunakan } \\
\text { dosen untuk memandu mahasiswa. }\end{array}$ & 1 & 1 & 3 & 3 & 3 & 4 & 4 & 3 \\
\hline 11. & $\begin{array}{l}\text { Alternatif jawaban dalam panduan LKM secara konsep } \\
\text { benar. }\end{array}$ & 1 & 1 & 4 & 3 & 3 & 3 & 4 & 3 \\
\hline 12. & $\begin{array}{l}\text { Peralatan dan bahan yang diperlukan realistis untuk } \\
\text { kondisi perguruan tinggi negeri di Indonesia. }\end{array}$ & 3 & 3 & 4 & 3 & 3 & 3 & 4 & 3 \\
\hline 13. & $\begin{array}{l}\text { LKM dapat mengembangkan sikap toleransi dan keadilan } \\
\text { sosial. }\end{array}$ & 3 & 2 & 2 & 3 & 3 & 4 & 4 & 3 \\
\hline 14. & $\begin{array}{l}\text { Mahasiswa dapat mengambil hikmah setelah mengerjakan } \\
\text { LKM. }\end{array}$ & 1 & 2 & 1 & 2 & 3 & 3 & 4 & 3 \\
\hline
\end{tabular}

Keterangan:

Skor 1: Tidak Baik Skor 2: Cukup

Tabel 1 menunjukkan bahwa pada tahap 1 sebagian besar modus pencapaian skor LKM Mata Kuliah Dasar-dasar IPA yang memiliki empat kegiatan (LKM 1, LKM 2, LKM 3, dan LKM 4) adalah 3 dan 4 yang masuk dalam kategori Baik dan Sangat Baik. Namun, ada beberapa komponen yang masih memiliki nilai kurang dan cukup pada LKM Dasar-dasar IPA.

Pada tahap 1 dan 2 LKM Dasar-dasar IPA telah memenuhi komponen no. 1 "LKM sesuai dengan model ALLR". Aktivitas yang dikembangkan dalam LKM telah mengikuti alur kegiatan yang dilakukan dengan model ALLR, dimulai dari pengarahan mahasiswa pada permasalahan yang akan dipecahkan, perumusan masalah, pembuatan hipotesis, perencanaan eksperimen atau percobaan, analisis data, dan pembuatan kesimpulan.

Kegiatan ini akan dilakukan melalui diskusi kelompok yang heterogen agar mahasiswa dapat melatih sikap kekeluargaan dan gotong royong dalam bekerja sama untuk menyelesaikan tugas. Diskusi yang dilakukan diarahkan pada penerapan konsep-konsep dalam bidang studi IPA dengan scaffolding dari dosen. Kegiatan dalam LKM Dasar-dasar IPA memang sengaja dirancang berpusat pada mahasiswa. Hal ini berkaitan dengan paradigma pendidikan yang berkembang dari pandangan behaviorisme ke pandangan konstruktivisme yang menekankan bahwa pemindahan informasi mengarah pada pemberian pengalaman dan pengembangan berpikir (kognisi). Peran guru berubah menjadi fasilitator yang
Skor 3: Baik

Skor 4: Sangat Baik

memfasilitasi siswa agar mampu belajar secara mandiri (Subanji, 2010).

Hal ini juga sesuai dengan Undang-Undang Republik Indonesia Nomor 20 Tahun 2003 tentang Sistem Pendidikan Nasional dan UndangUndang Republik Indonesia Nomor 12 Tahun 2012 tentang Pendidikan Tinggi menyatakan bahwa pembelajaran merupakan interaksi antara pendidik, peserta didik, sumber belajar di dalam lingkungan belajar tertentu. Hal ini berarti pembelajaran harus berpusat pada mahasiswa dengan dosen yang berperan sebagai fasilitator dan motivator. Mahasiswa harus menunjukkan kinerja yang kreatif dan mampu mengintegrasikan kemampuan kognitif, psikomotor, dan afektif secara utuh yang menitikberatkan pada metode inkuiri dan penemuan.

Tabel 1 menunjukkan bahwa LKM 1, LKM 2, dan LKM 4 telah mencapai skor 3 dengan kategori "Baik" untuk komponen no. 5 "masalah merupakan penerapan konsep-konsep dalam bidang studi IPA dengan scaffolding dari dosen". Namun, LKM 3 mendapatkan skor 2 yang termasuk dalam kategori "Cukup". Validator memberikan saran untuk mengganti permasalahan yang diangkat menjadi permasalahan yang diarahkan pada pemodelan matematis dalam bidang Fisika. Setelah melakukan revisi, skor LKM 3 pada validasi tahap ke dua mendapat nilai 3 yang termasuk dalam kategori "Baik" untuk komponen no. 5 ini.

Kegiatan dalam LKM Dasar-dasar IPA memiliki arahan yang berfungsi sebagai bantuan 
bagi mahasiswa untuk memamahi kegiatan yang akan dilakukan selama proses pembelajaran (Komponen no. 7). Tabel 1 menunjukkan bahwa arahan dalam LKM 1, LKM 2, dan LKM 3 mendapat skor 2 yang berkategori "Cukup". Validator menyarankan untuk merevisi redaksional arahan dalam LKM tersebut. Setelah dilakukan revisi, penilaian dari validator mengalami peningkatan menjadi skor 3 dengan kategori "Baik" untuk komponen no.7. Demikian juga, komponen no. 8 tentang informasi dalam LKM untuk LKM 3 memerlukan revisi dalam hal redaksional agar tidak memiliki penafsiran ganda. Penggunaan bahasa yang baik dalam penulisan suatu bahan bacaan diperlukan agar komunikasi tertulis juga dapat berjalan dengan baik dan tidak memiliki makna ganda. LKM yang baik adalah LKM yang menggunakan bahasa tertulis dengan baik menurut EYD dan tidak bermakna ganda.

Komponen no. 9 "alternatif jawaban dalam LKM" menunjukkan bahwa LKM 1 dan LKM 2 mendapatkan skor 1 dengan kategori "Kurang" pada kegiatan validasi tahap 1 . Hal ini karena LKM 1 dan LKM 2 belum dilengkapi dengan alternatif jawaban. Validator memberikan saran untuk memberikan kunci jawaban yang dapat menjadi alternatif jawaban LKM tersebut Setelah dilakukan revisi dan validasi tahap 2, LKM 1 dan LKM 2 mendapat kategori "Baik" dan "Baik Sekali". Demikian juga, komponen no. 11 kebenaran konsep dalam alternative jawaban dalam LKM 1 dan LKM 2.

Komponen no. 12 "kerealistisan alat dan bahan yang digunakan dalam aktivitas dengan kondisi di Perguruan Tinggi Negeri di Indonesia" mendapat skor 3 dengan kategori "Baik" untuk LKM 1, LKM 2, dan LKM 4, sementara LKM 3 mendapat skor 4 dengan kategori "Baik Sekali". Rancangan kegiatan berupa penentuan alat, bahan, dan prosedur kerja yang tercantum dalam LKM Dasar-dasar IPA bersifat fleksibel dalam arti mahasiswa boleh memodifikasi dengan menggunakan dasar teori disertai alasan yang logis. Validator menyarankan bahwa hal tersebut sebaiknya dicantumkan dalam LKM sehingga mahasiswa tahu bahwa perancangan aktivitas tidak terbatas pada rancangan kegiatan yang tersedia dalam LKM. Selain itu, dosen lain yang menggunakan LKM ini dapat mengetahuinya juga.

Sementara itu, komponen no. 13 "pengembangan sikap toleransi dan keadilan sosial" pada tahap 1 yang trtulis dalam Tabel 1 untuk LKM 2 dan LKM 3 termasuk dalam kategori "Cukup". Validator memberikan saran untuk memberikan fitur-fitur yang dapat mengingatkan mahasiswa untuk selalu bekerja, saling menghargai, dan bergotong royong dalam nuansa kekeluargaan sehingga mahasiswa sadar arti penting kegiatan kelompok yang dilakukan. Berdasarkan saran tersebut, LKM 1, LKM 2, LKM 3, dan LKM 4 direvisi dan diberi tambahan fitur "Character Building" untuk mengingatkan mahasiswa tentang arti penting kegiatan berkelompok yang mereka lakukan.

Komponen no. 14 "pengambilan hikmah" juga memerlukan perbaikan karena mendapat skor 1 dengan kategori "Kurang" untuk LKM 1 dan LKM 3 dan skor 2 dengan kategori "Cukup" untuk LKM 2 dan LKM 4. Perbaikan yang disarankan validator adalah memberikan contoh pengambilan hikmah agar mempermudah mahasiswa untuk mempelajari sesuatu yang baru. Contoh yang diberikan sebaiknya contoh sederhana yang dapat diambil dari kehidupan sehari-hari mahasiswa. Selain itu, validator memberikan saran untuk menyediakan subkegiatan refleksi agar mahasiswa mengetahui bahwa refleksi kegiatan merupakan bagian penting dari pembelajaran.

Pendidikan tidak hanya sekedar membantu pertumbuhan fisik saja namun juga membantu perkembangan pribadi masnusia dalam lingkungan yang memiliki peradaban. Pendidikan merupakan pewarisan kebudayaan dari generasi tua ke generasi muda agar hidup bermasyarakat tetap berkelanjuta (Langgulung, 1988). Hal ini sejalan dengan pendapat bahwa nilai-nilai budaya harus disalurkan dari generasi ke generasi agar identitas masyarakat tersebut tetap terpelihara melalui sekolah-sekolah, perguruan tinggi, universitas, dan instituri lain, berupa akumulasi pengetahuan, nilai, dan keterampilan dari generasi ke generasi lain (Kneller, 1967). Hal inilah yang melandasi dimasukkannya fitur-fitur dan aktivitas yang dapat menguatkan karakter mahasiswa. Dalam LKM ini fitur "Character Building", aktivitas pengambilan hikmah, dan aktivitas refleksi diintegrasikan dalam pembelajaran dengan tujuan pendidikan karakter calon guru IPA.

Tabel 1 menunjukkan pada tahapan pertama beberapa komponen memerlukan perbaikan karena masih dalam kategori "Cukup" dan "Kurang. Hasil perbaikan berdasarkan saran dari validator menjadikan LKM Dasar-dasar IPA yang dikembangkan memiliki kategori "Baik" dan "Baik Sekali" untuk setiap komponen yang divalidasi, baik dari segi bahasa, kegiatan, maupun fitur-fitur yang diharapkan dapat meningkatkan keterampilan proses sains mahasiswa dan menguatkan sikap toleransi dan keadilan sosial mahasiswa. Hasil validasi dianalisis menggunakan skala Likert dengan mengguakan rumus sebagai berikut. 
$\operatorname{Persentase}(\%)=\frac{\text { Modus Skor hasil validasi }}{\text { Skor kriteria }} \times 100 \%$

(Riduwan, 2011)
Hasil perhitungan analisis tersebut tertulis dalam Tabel 2. LKM dianggap valid dan layak untuk digunakan apabilan mencapai persentasi $\geq$ 61\% (Riduwan, 2011).

Tabel 2 Analisis Validasi LKM Dasar-dasar IPA

\begin{tabular}{|c|c|c|c|c|c|}
\hline \multirow[t]{2}{*}{ No } & \multirow[t]{2}{*}{ LKM Dasar-Dasar IPA } & \multirow{2}{*}{$\begin{array}{r}\text { Tahap } 1 \\
\text { Persentase } \\
\text { Skor }(\%)\end{array}$} & \multicolumn{3}{|c|}{ Tahap 2} \\
\hline & & & Kriteria & $\begin{array}{c}\text { Persentase } \\
\text { Skor }(\%)\end{array}$ & Kriteria \\
\hline 1 & $\begin{array}{l}\text { LKM } 1 \text { Inkuiri dalam IPA (Faktor- } \\
\text { faktor yang Mempengaruhi Kapilaritas) }\end{array}$ & 60.71 & $\begin{array}{l}\text { Cukup } \\
\text { Valid }\end{array}$ & 76.79 & Valid \\
\hline 2 & $\begin{array}{l}\text { LKM } 2 \text { Pemodelan dalam IPA (Kasus } \\
\text { Peran Vegetasi dalam Mengurangi } \\
\text { Global Warming) }\end{array}$ & 60.71 & $\begin{array}{c}\text { Cukup } \\
\text { Valid }\end{array}$ & 82.14 & $\begin{array}{c}\text { Sangat } \\
\text { Valid }\end{array}$ \\
\hline 3 & $\begin{array}{l}\text { LKM } 3 \text { Pemodelan Matematis dalam } \\
\text { IPA (Kasus Pengaruh Gaya terhadap } \\
\text { Pertambahan Panjang Pegas) }\end{array}$ & 67.86 & Valid & 92.85 & $\begin{array}{c}\text { Sangat } \\
\text { Valid }\end{array}$ \\
\hline 4 & $\begin{array}{l}\text { LKM } 4 \text { Pemodelan Matematis dalam } \\
\text { IPA (Kasus Pembentukan Ikatan Ion) }\end{array}$ & 75 & Valid & 76.78 & Valid \\
\hline
\end{tabular}

Tabel 2 menunjukkan bahwa penilaian LKM Dasar-dasar IPA termasuk dalam kategori "Cukup Valid" untuk LKM 1 dan LKM 2 dan "Valid" untuk LKM 3 dan LKM 4. Setelah melakukan revisi dan validasi ulang di tahap 2, LKM 1, LKM 3, dan LKM 4 berkriteria "Valid" dan LKM 3 berkriteria "Sangat Valid". Hasil analisis menunjukkan bahwa LKM 1, LKM 2, LKM 3, dan LKM 4 layak untuk digunakan dalam kegiatan pembelajaran menurut hasil validasi ahli.

\section{SIMPULAN DAN SARAN}

\section{Simpulan}

LKM Dasar-dasar IPA berbasis model pembelajaran ALLR layak digunakan dalam perkuliahan Dasar-dasar IPA berdasarkan validitas LKM tersebut.

\section{Saran}

Saran yang perlu diperhatikan dalam penelitian selanjutnya adalah penggunaan LKM Dasar-dasar IPA ini memerlukan pemahaman bagi dosen untuk mengintegrasikan pendidikan karakter dalam proses pembelajaran sehingga mahasiswa tidak hanya menguasai konten-konten IPA yang tertulis dalam capaian kompetensi Mata Kuliah Dasar-dasar IPA.

\section{DAFTAR PUSTAKA}

Carin, A.A. dan Sund, R.B. 1990. Teaching Science Through Discovery $4^{\text {th }} E d$. Ohio: Charles E. Merill Publishing Company.

Hakim, R.N. 2016a. Survei Wahid Foundation: Indonesia Masih Rawan Intoleransi dan Radikalisme. diunduh pada tanggal 1 Agustus
2016 dari

https://nasional.kompas.com/read/2016/08/01/ 13363111/survei.wahid.foundation.indonesia. masih.rawan.intoleransi.dan.radikalisme

Hakim, R.N. 2016b. RI Masih Rentan Intoleransi, Wahid Foundation Sampaikan Enam Rekomendasi. diunduh pada tanggal 1 Agustus 2016 dari http://wahidfoundation.org/index.php/news/de tail/RI-Masih-Rentan-Intoleransi-WahidFoundation-Sampaikan-Enam-Rekomendasi

Kneller, G.F. 1967. The philosopy of education. New York : London Sydney.

Langulung, Hasan. 1988. Asas-asas Pendidikan Islam. Jakarta :Pustaka Al-Husna.

Prasasti, P.A.T. 2017. Efektivitas Scientific Approach With Guided Experiment Pada Pembelajaran Ipa Untuk Memberdayakan Keterampilan Proses Sains Siswa Sekolah Dasar. Profesi Pendidikan Dasar, Vol. 4, No. 1, pp. $19-26$.

Riduwan. 2011. Skala Pengukuran Variabelvariabel Penelitian. Bandung: Alfabeta.

Sugiyono. 2018. Metode Penelitian Pendidikan (Pendekatan Kuantitatif, Kualitatif, dan $R \& D)$. Bandung: Alfabeta.

Shumow, Lee dan Jennifer A. Schmidt. 2014. "Teaching the Value of Science". STEM for All. Vol. 72 (4): hal. 62-67.

Widodo, W., Suyanto, T., Martini, dan Sari, D.A.P Sari. 2018a. Developing Tolerance and Social Justice Attitudes Through Learning Subjects: ALLR Learning Model. Proceeding of The $11^{\text {th }}$ International Conference on Educational Research, Faculty of Education, Khon Kaen University, Thailand. 
Widodo, W., Suyanto, T., Martini, dan Sari, D.A.P Sari. 2018b. Model Pembelajaran ALLR (Activity Based-Lesson LearnReflection) Penguatan Sikap Toleransi dan Keadilan Sosial. Surabaya: Unesa University Press.

Subanji dan Isnandar. 2010. Meningkatkan Profesionalisme Guru Sekolah Dasar melalui Teachers Quality Improvement Program (TEQIP) Berbasis Lesson Study. 2 , J-TEQIP, Tahun 1, No. 1, pp. 1-11.

Trianto. 2010. Model Pembelajaran Terpadu. Jakarta: PT. Bumi Aksara.
Undang-Undang Republik Indonesia Nomor 12 Tahun 2012 tentang Pendidikan Tinggi.

Undang-Undang Republik Indonesia Nomor 20 Tahun 2003 tentang Sistem Pendidikan Nasional.

Zuchdi, D., Prasetya, Z.K., dan Masruri, M.S. 2010. Pengembangan Model Pendidikan Karakter Terintegrasi dalam Pembelajaran Bidang Studi di Sekolah Dasar. Jurnal Ilmiah Pendidikan Cakrawala Pendidikan Edisi Khusus Dies Natalis UNY, No. 3. 